\title{
Supporting Information: Hydroxymethanesulfonate (HMS) Formation during Summertime Fog in an Arctic Oil Field
}

Jun Liu ${ }^{1}$, Matthew J. Gunsch ${ }^{1}$, Claire E. Moffett ${ }^{2}, \mathrm{Lu} \mathrm{Xu}^{3}$, Rime El Asmar ${ }^{4}$, Qi Zhang ${ }^{5}$, Thomas B. Watson ${ }^{6}$, Hannah M. Allen ${ }^{3}$, John D. Crounse ${ }^{7}$, Jason St. Clair ${ }^{8,9}$, Michelle $\mathrm{Kim}^{7}$, Paul O. Wennberg ${ }^{3,7}$, Rodney J. Weber ${ }^{4}$, Rebecca J. Sheesley ${ }^{2}$, and Kerri A. Pratt $^{1,10^{*}}$

${ }^{1}$ Department of Chemistry, University of Michigan, Ann Arbor, MI, USA

${ }^{2}$ Department of Environmental Science, Baylor University, Waco, TX, USA

${ }^{3}$ Division of Geological and Planetary Sciences, California Institute of Technology, Pasadena, CA, USA

${ }^{4}$ Department of Environmental Toxicology, University of California, Davis, CA, USA

${ }^{5}$ School of Earth and Atmospheric Sciences, Georgia Institute of Technology, Atlanta, GA, USA

${ }^{6}$ Department of Environmental and Climate Sciences, Brookhaven National Laboratory, Upton, NY, USA

${ }^{7}$ Division of Engineering and Applied Science, California Institute of Technology, Pasadena, CA, USA

${ }^{8}$ Atmospheric Chemistry and Dynamics Lab, NASA Goddard Space Flight Center, Greenbelt, MD, USA

${ }^{9}$ Joint Center for Earth Systems Technology, University of Maryland Baltimore County, Baltimore, MD, USA

${ }^{10}$ Department of Earth \& Environmental Sciences, University of Michigan, Ann Arbor, MI, USA

*Corresponding Author: prattka@umich.edu 


\section{ToF-ACSM measurements and excess sulfate mass estimation}

Non-refractory particulate matter $<1 \mu \mathrm{m}\left(\mathrm{NR}-\mathrm{PM}_{1}\right)$ mass concentrations of organics, sulfate, nitrate, ammonium, and chloride were measured by the ToF-ACSM ${ }^{1,2}$ at the Oliktok Point field site from August 18 to September 20, 2016. These data were previously reported and discussed by Gunsch et al. ${ }^{3}$ ToF-ACSM NR-PM 1 sulfate mass concentrations were correlated with $\mathrm{PM}_{1}$ sulfate measured by IC $\left(\mathrm{r}^{2}=0.74\right)$ (Figure S6). Previously, Zhou et al. ${ }^{4}$ showed good correlation between the online aerosol mass spectrometer, ACSM, and particle-into-liquid sampler (PILS)-IC measurements of sulfate at a mid-latitude coastal site.

ToF-ACSM data have previously been used to estimate HMS mass concentrations. ${ }^{5-7}$ We followed equation 1 in Song et. al. ${ }^{7}$ to estimate the ToF-ACSM excess $\mathrm{SO}^{+}$and $\mathrm{SO}_{2}^{+}$ (excess sulfate) mass, attributed to organosulfate compounds. For inorganic sulfate, $\mathrm{SO}^{+}$ and $\mathrm{SO}_{2}^{+}$signals were assumed to contribute to a constant fraction of $\mathrm{H}_{y} \mathrm{SO}_{\mathrm{x}}^{+}$, which is the sum of $\mathrm{SO}^{+}, \mathrm{SO}_{2}^{+}, \mathrm{SO}_{3}^{+}, \mathrm{HSO}_{3}^{+}$, and $\mathrm{H}_{2} \mathrm{SO}_{4}^{+}{ }^{8}$ The two fractions, $\mathrm{SO}^{+} / \mathrm{H}_{y} \mathrm{SO}_{\mathrm{x}}^{+}$and $\mathrm{SO}_{2}^{+} / \mathrm{H}_{2} \mathrm{SO}_{4}^{+}$in inorganic sulfate, were determined for time periods when they were both low and stable. The excess mass was then calculated by subtracting the calculated $\mathrm{SO}^{+}$and $\mathrm{SO}_{2}^{+}$mass, assumed to be exclusively inorganic sulfate using these fractions, from the measured $\mathrm{SO}^{+}$and $\mathrm{SO}_{2}^{+}$mass.

ToF-ACSM measurements suggest that excess sulfate could, on average, contribute $30 \%\left(0.07 \mu \mathrm{g} / \mathrm{m}^{3}\right)$ of NR-PM "sulfate" and $6 \%$ of total NR-PM 1 mass at Oliktok Point (Figure S4). For comparison, Song et al. ${ }^{7}$ used this approach, assuming excess sulfate to be HMS as an upper bound, and estimated the HMS contribution to be $\mathrm{PM}_{1}$ sulfate in Beijing winter haze to be $17 \%$. However, the uncertainty in such a HMS estimation is 
high. ${ }^{9-12}$ In this study, no correlation was observed between the calculated HMS production rate and the rate of change in the ToF-ACSM excess $\mathrm{SO}^{+}$and $\mathrm{SO}_{2}^{+}$mass $(\mathrm{R}=-0.02)$, thereby inhibiting the ability to determine the contribution of $\mathrm{HMS}$ to the excess $\mathrm{SO}^{+}$and $\mathrm{SO}_{2}^{+}$mass (excess sulfate). The ToF-ACSM excess sulfate mass concentrations were $\sim 60$ times higher, on average, than the IC HMS mass concentrations for filter sample time periods with signals above the limit of detection (Figure S4).

Excess $\mathrm{SO}^{+}$and $\mathrm{SO}_{2}^{+}$mass was $4 \%$ lower in fog periods compared to no-fog periods, supporting compounds beyond HMS contributing to the excess $\mathrm{SO}^{+}$and $\mathrm{SO}_{2}^{+}$mass. One of the other possible causes for different levels of excess $\mathrm{SO}^{+}$and $\mathrm{SO}_{2}^{+}$signals is the possible variation in the relative abundance of inorganic sulfates, such as $\left(\mathrm{NH}_{4}\right)_{2} \mathrm{SO}_{4}, \mathrm{NH}_{4} \mathrm{HSO}_{4}$, and $\mathrm{H}_{2} \mathrm{SO}_{4} \cdot{ }^{9}{ }^{10}$ Fragmentation of organosulfates sometimes can be indistinguishable from inorganic sulfates, ${ }^{11}$ which also adds to the uncertainty of this estimation. A recent study also showed that the quantification of different sulfur organic compounds with this method is challenging, as the fragmentation patterns only have subtle differences and are sensitive to matrix effects. ${ }^{12}$

In this study, no apparent correlation was found between RH and the ToF-ACSM total sulfate mass concentration ( $\mathrm{R}=0.01)$, or between $\mathrm{RH}$ and the ATOFMS HMS-containing particle number fraction $(\mathrm{R}=0.12)$, in contrast to several previous HMS studies in midlatitude polluted sites. ${ }^{5,7,13}$ The ToF-ACSM sulfate mass concentration was also not enhanced during fog periods. Nevertheless, the positive relationship between fog periods and the presence and abundance of HMS within individual particles supports the role of fog processing in HMS formation in the Arctic oil field. 


\section{Mass transport processes of $\mathrm{SO}_{2}$ and $\mathrm{HCHO}$ at the gas-liquid interface, in the gas phase, and within fog droplets}

The mass transport processes include diffusion of $\mathrm{HCHO}$ and $\mathrm{SO}_{2}$ in the gas and aqueous phases, and their equilibrium at the gas-liquid interface. The characteristic times of these processes were calculated to determine if they limit the rate of this aqueous reaction. The following equations (1-5) are from Seinfeld and Pandis. ${ }^{14} \mathrm{We}$ did not examine the characteristic times of the aqueous-phase dissociation reactions here because they tend to be short as compared with all timescales of interest. ${ }^{14}$ The characteristic time for gas-phase diffusion to a particle is described as:

$$
\tau_{d g}=\frac{R_{p}^{2}}{D_{g}}
$$

where $R_{p}$ is the fog droplet size, assumed to be $10 \mu \mathrm{m}$ based on previous fog droplet size distributions measurements on the North Slope of Alaska. ${ }^{15} D_{g}$ is the diffusion coefficient of $\mathrm{SO}_{2}\left(1.03 \times 10^{-5} \mathrm{~m}^{2} \mathrm{~s}^{-1}\right)^{16}$ or $\mathrm{HCHO}\left(1.8 \times 10^{-9} \mathrm{~m}^{2} \mathrm{~s}^{-1}\right)^{17}$ in the gas phase. The characteristic time to achieve equilibrium at the gas-liquid interface (s) is described as:

$$
\tau_{\text {surface }}=2 \pi M R T D_{a q}\left(H_{A}^{*}\right)^{2}
$$

where $\mathrm{M}$ is molecular weight, $\mathrm{R}$ is the universal gas constant, $\mathrm{T}$ is temperature, $D_{a q}$ is the diffusion coefficient of $\mathrm{SO}_{2}\left(1.62 \times 10^{-10} \mathrm{~m}^{2} \mathrm{~s}^{-1}\right)^{16}$ or HCHO $\left(2 \times 10^{-10} \mathrm{~m}^{2} \mathrm{~s}^{-1}\right)^{17}$ in the aqueous phase, $H_{A}^{*}$ is the Henry's law constant (HCHO: $0.1593 \mathrm{~mol} \mathrm{~m}^{-3} \mathrm{~Pa}^{-1} ; \mathrm{SO}_{2}: 0.0288$ mol m $\left.\mathrm{m}^{-3} \mathrm{~Pa}^{-1}\right)$ at the campaign average temperature $(276 \mathrm{~K}) .{ }^{18}$ The characteristic time of aqueous-phase diffusion in a droplet is described as:

$$
\tau_{d a}=\frac{R_{p}^{2}}{\pi^{2} D_{a q}}
$$


The characteristic times of mass transport described above were compared to the characteristic time for aqueous phase chemical reactions:

$$
\begin{aligned}
& \tau_{H C H O}=\frac{1}{\left(\mathrm{k}_{1} \alpha_{1}+\mathrm{k}_{2} \alpha_{2}\right)\left[\mathrm{SO}_{2(\mathrm{aq})}\right]} \\
& \tau_{\mathrm{SO}_{2}}=\frac{1}{\left(\mathrm{k}_{1} \alpha_{1}+\mathrm{k}_{2} \alpha_{2}\right)\left[\mathrm{HCHO}_{(\mathrm{aq})}\right]}
\end{aligned}
$$

The measured gas phase mole ratios of $\mathrm{SO}_{2}$ and $\mathrm{HCHO}$ in Table $\mathrm{S} 1$ were examined here. $\mathrm{HCHO}$ hydration and dehydration were previously reported to be fast and generally not rate-limiting for HMS production., ${ }^{7,}, 20$

For a fog droplet with $\mathrm{pH} 5$, the average characteristic time for aqueous phase chemical reaction ranged from 10 to $3000 \mathrm{~h}$ for both $\mathrm{HCHO}$ and $\mathrm{SO}_{2}$. In comparison, the characteristic times under the same $\mathrm{pH}$ for gas-phase diffusion, aqueous diffusion, and gasliquid interface equilibrium ranged from $1 \times 10^{-12}$ to $6 \times 10^{-3} \mathrm{~s}$. Therefore, the characteristic times of mass transport were at least six orders of magnitudes smaller than the characteristic time for aqueous phase chemical reactions. Thus, these mass transfer processes are not rate-limiting factors in HMS formation in fog droplets and do not need to be taken into account for the HMS production rate calculation. 


\section{Single-particle chemical characterization}

ATOFMS single-particle chemical characterization during this study is described by Gunsch et al. ${ }^{3}$ The 32,880 individual particle mass spectra were clustered using the neural network algorithm ART-2a. ${ }^{21}$ Eight unique individual particle types were identified based on the presence and intensity of ion peaks with comparison to previous laboratory and field studies. $^{22}$ The characteristic mass spectra for each of the single-particle types (sea spray aerosol (SSA), elemental carbon (EC), EC and organic carbon (ECOC), OC-amine-sulfate, OC, biomass burning, mineral dust, and incineration particles) are described in detail by Gunsch et al. ${ }^{3}$ Briefly, OC-amine-sulfate particles, which accounted for $81 \%$, by number, of the HMS-containing particles, were characterized by OC (e.g., $m / z 27, \mathrm{C}_{2} \mathrm{H}_{3}{ }^{+}$), sulfate $\left(\mathrm{m} / \mathrm{z}-97, \mathrm{HSO}_{4}{ }^{-}\right)$, and alkylamines $(\mathrm{m} / \mathrm{z} 58,59,72,86,101$, and 118$)$. The OC-aminesulfate particles were most abundant during oil field plumes, with diethylamine and trimethylamine attributed to anthropogenic sources within the oil field and trimethylamine from biogenic sources. ${ }^{3}$. ECOC particles, which contributed to $15 \%$, by number, of the HMS-containing particles showed high degree of similarity to particles from diesel combustion, and were identified by carbon cluster ions $\left(\mathrm{C}_{\mathrm{n}}^{+/-}\right)$, OC $\left(m / z 27, \mathrm{C}_{2} \mathrm{H}_{3}{ }^{+}\right)$, oxidized OC $\left(m / z 43, \mathrm{C}_{2} \mathrm{H}_{3} \mathrm{O}^{+}\right)$, sulfate $\left(m / z-97, \mathrm{HSO}_{4}{ }^{-}\right)$, and sulfuric acid $(\mathrm{m} / \mathrm{z}-195$, $\mathrm{H}_{2} \mathrm{SO}_{4} \mathrm{HSO}_{4}{ }^{-}$). SSA particle mass spectra featured abundant sodium and chloride peaks. EC particle mass spectra were characterized by carbon cluster ions and phosphate. The OC particle type featured only positive ions, including $m / z 27\left(\mathrm{C}_{2} \mathrm{H}_{3}{ }^{+}\right), 37\left(\mathrm{C}_{3} \mathrm{H}^{+}\right)$, and 43 $\left(\mathrm{C}_{2} \mathrm{H}_{3} \mathrm{O}^{+}\right)$. The biomass burning particles also included only positive ions, including an intense $m / z 39\left(\mathrm{~K}^{+}\right)$, plus organic carbon peaks. The lack of negative ions is indicative of the accumulation of water during transport. ${ }^{23}$ The incineration particles featured an intense 
$m / z 39\left(\mathrm{~K}^{+}\right)$, as well $m / z 113,115,117\left(\mathrm{~K}_{2} \mathrm{Cl}^{+/}\right)$, as well as nitrate $(m / z-46,62)$ and copper $(\mathrm{m} / \mathrm{z} 63,65)$. Only the incineration particles contained both potassium and chloride, suggesting a likely interference of $\mathrm{KCl}_{2}{ }^{-}$at $m / z-111$, as noted in the main text. Additional details about the source attributions, number and mass concentrations, and time series of these particle types are described by Gunsch et al. ${ }^{3}$ 


\section{PM1 filter sampling and ion chromatography (IC) analysis}

The $\mathrm{PM}_{1}$ medium volume sampler (URG Corp., Chapel Hill, NC) was elevated on a platform $\sim 10 \mathrm{~m}$ above ground level. The sample flow was split into two filter lines, with the quartz line having a flow rate of $82 \mathrm{~L} \mathrm{~min}^{-1}$. The flow rate was checked prior to each sample with a calibrated digital flowmeter. The $90 \mathrm{~mm}$ diameter quartz fiber filters (Pall Tissuquartz, Port Washington, NY) were baked prior to sampling at $500^{\circ} \mathrm{C}$ for $12 \mathrm{~h}$ and stored in aluminum foil-lined petri dishes (foil was also baked at $500^{\circ} \mathrm{C}$ for $12 \mathrm{~h}$ ) and storage bags in a $-10^{\circ} \mathrm{C}$ freezer before and after sampling. Field blanks were taken periodically by placing an unsampled filter in the filter holder, placing it in the sampler momentarily, and then removing it and placing the filter in storage. Field blanks were treated in the same manner as sampled filters. Filters were shipped from Oliktok Point to Baylor University and then to Georgia Institute of Technology in a cooler with ice packs. Prior to filter extraction for IC measurement, a $1.5-4.5 \mathrm{~cm}^{2}$ section of each filter was removed for other analysis. The remaining filter was extracted in $15 \mathrm{~mL}$ of deionized water (>18 MOhm) by sonication for $30 \mathrm{~min}$ in $50 \mathrm{~mL}$ centrifuge tubes (89039-656, VWR International, LLC, Radnor, PA).

The IC analytical system included an autosampler (Dionex AS40, $5 \mathrm{~mL}$ vials with filtering cap, Thermo Fisher Scientific, Waltham, MA) and a Metrohm Peak Ion Chromatograph (Compact 761, Metrohm, Herisau, Switzerland). The IC was operated with a $250 \mu \mathrm{L}$ sample loop, a Metrosep A Supp 5-150/4.0 anion column with carbonate/bicarbonate eluent $\left(3.2 \mathrm{mM} \mathrm{Na}_{2}\left(\mathrm{CO}_{3}\right) / 1.0 \mathrm{mM} \mathrm{NaHCO}_{3}\right)$, isocratic separation, a flow rate of $0.70 \mathrm{~mL} / \mathrm{min}$, and conductivity detection. This method separates HMS $\left(\mathrm{HOCH}_{2} \mathrm{SO}_{3}{ }^{-}\right)$and sulfate $\left(\mathrm{SO}_{4}{ }^{2-}\right)$ peaks (Figure S2). The instrument was calibrated by 
serial dilution of liquid standards composed of a mix of ions (IV-STOCK-59-125 mL, Inorganic Ventures, Christianburg, VA), whereas the HMS standard was run separately. This standard was prepared from solid sodium hydroxymethanesulfonate (Na-HMS, 112704-100G, Sigma-Aldrich) that had been desiccated and then liquid concentrations were based on a gravimetric analysis of HMS (removing mass of $\mathrm{Na}^{+}$, i.e., measured NaHMS mass times 0.83$)$ and a known volume of pure (10 M $\Omega)$ water. The HMS defined here is the peak in the IC chromatogram that has the same retention time as this HMS standard. Calibrations show that a fraction of the HMS is converted to sulfate during the IC analysis (less than $2 \%$ of measured sulfate for these data), which means that sulfate is slightly over-estimated when HMS is present, whereas the loss of HMS is accounted for in the calibration. The sulfate limit of detection ranged from $0.8-3 \mathrm{ng} / \mathrm{m}^{3}$. 


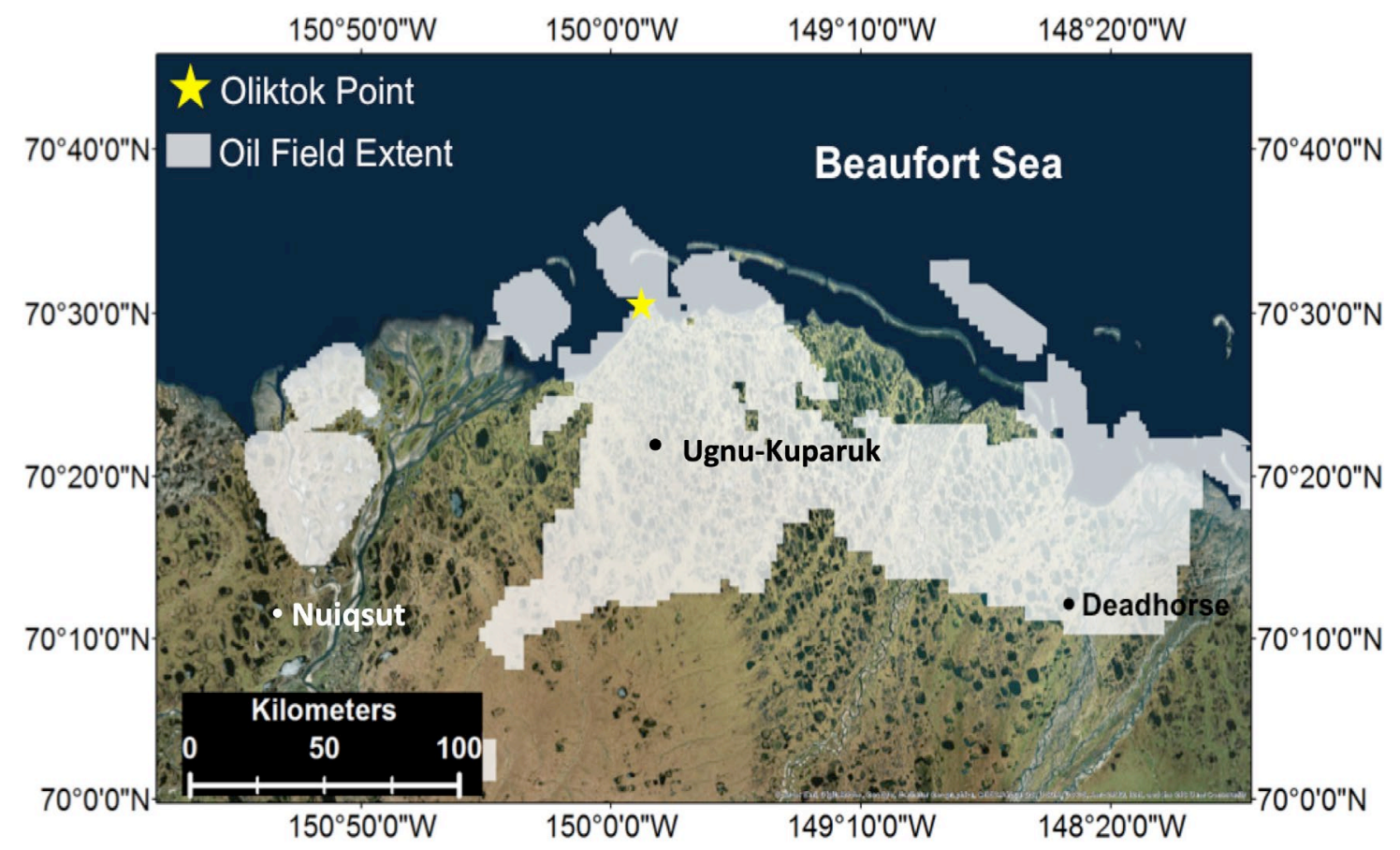

Figure S1. Map of the North Slope of Alaska oil field extent, and the location of the three closest airports (Nuiqsut, Deadhorse, and Ugnu-Kuparuk). The map background was acquired by ArcGIS 10.3.1 with the World Imagery basemap. Oil field extent was obtained from http://dog.dnr.alaska.gov. 

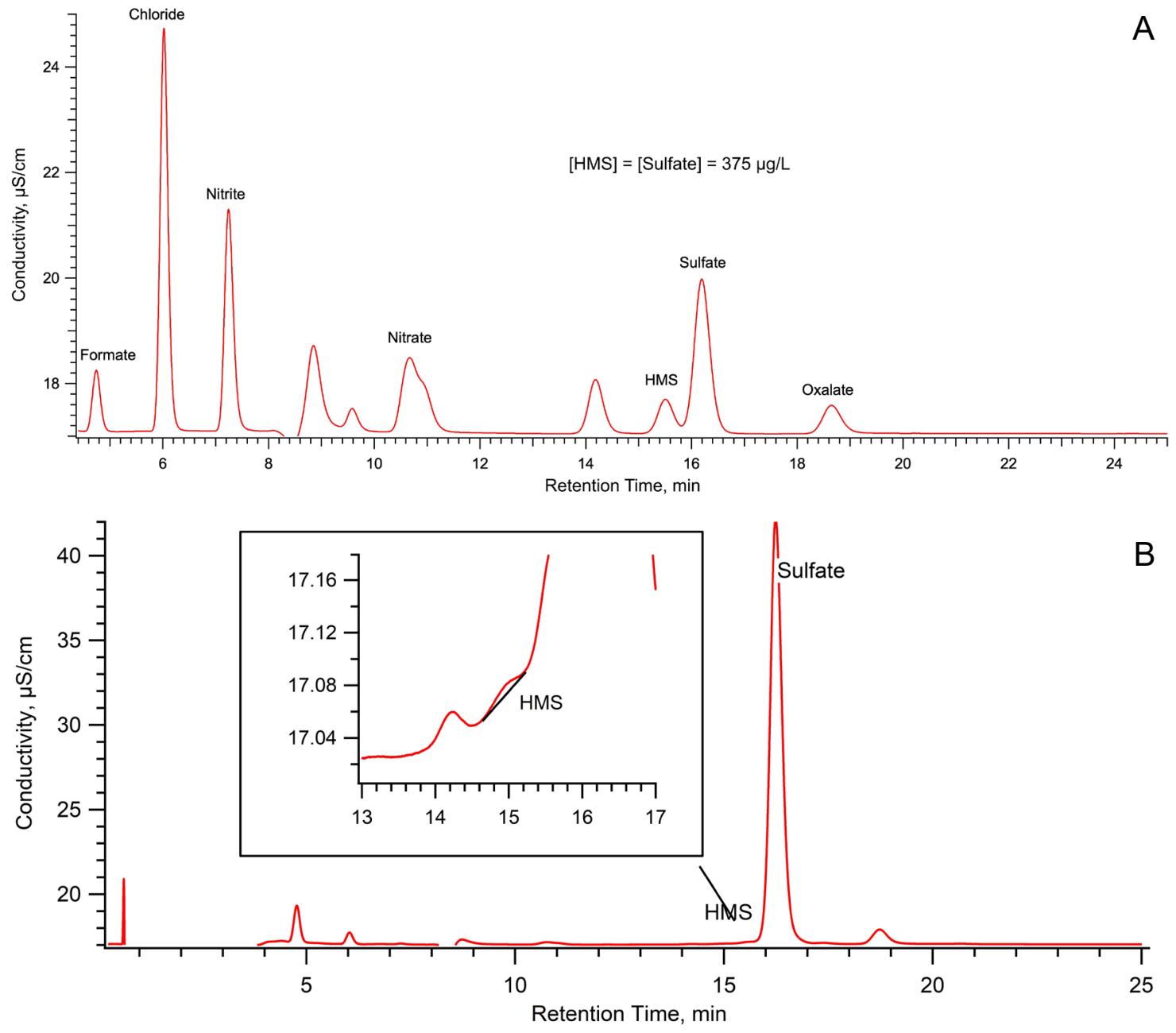

Figure S2. A) Mixed standard solution and B) example ambient (Sep. 7-11, 2018 sample) IC chromatograms showing separation of HMS and sulfate. 

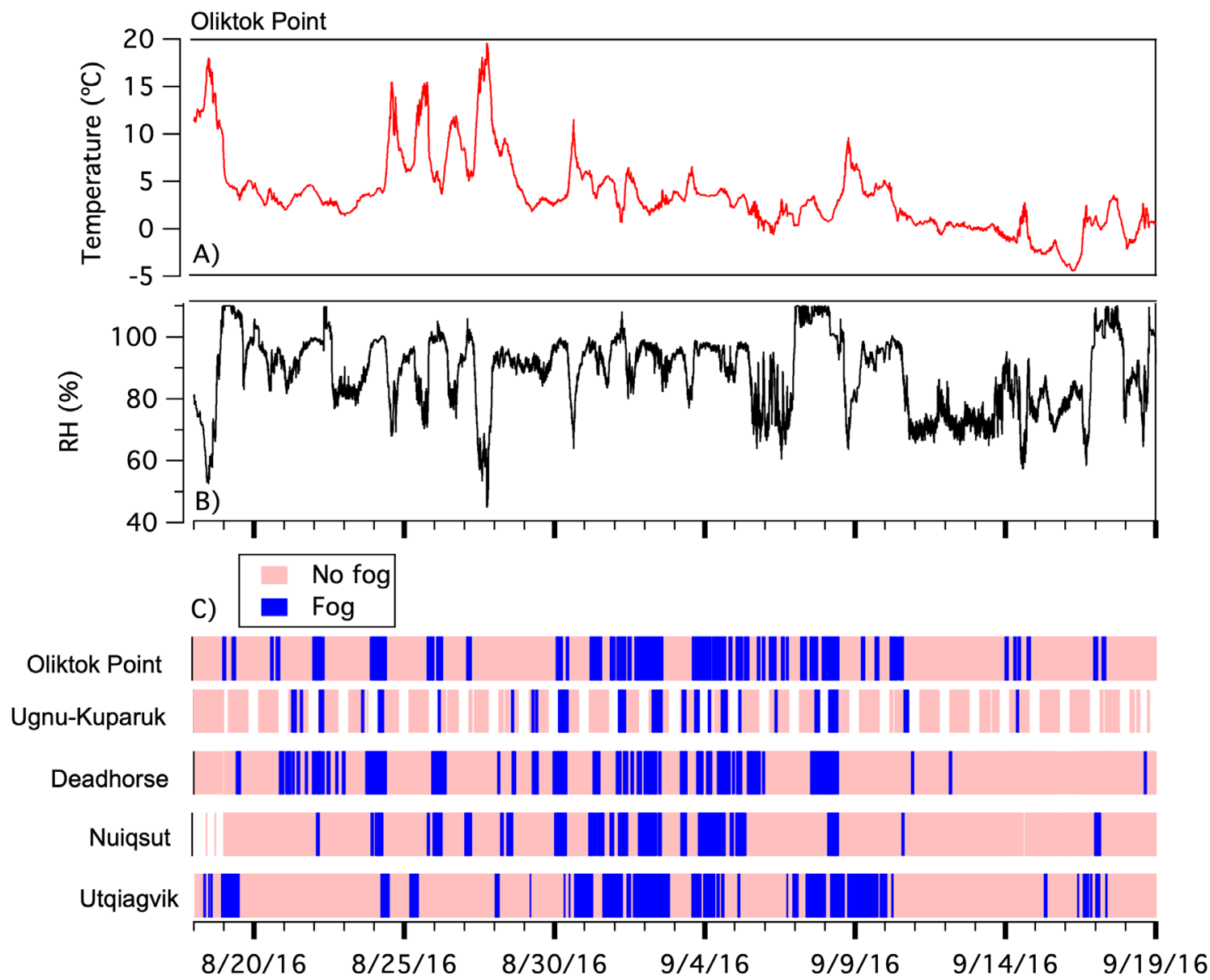

Figure S3. A) Temperature and B) relative humidity $(\mathrm{RH})$ measured at Oliktok Point, AK. C) Observed fog periods from meteorological measurements at Oliktok Point and weather archives (https://www.weatherforyou.com) at Utqiagvik and the three nearby airports (Ugnu-Kuparuk, Deadhorse, and Nuiqsut). Periods with no data are shown as white gaps. 


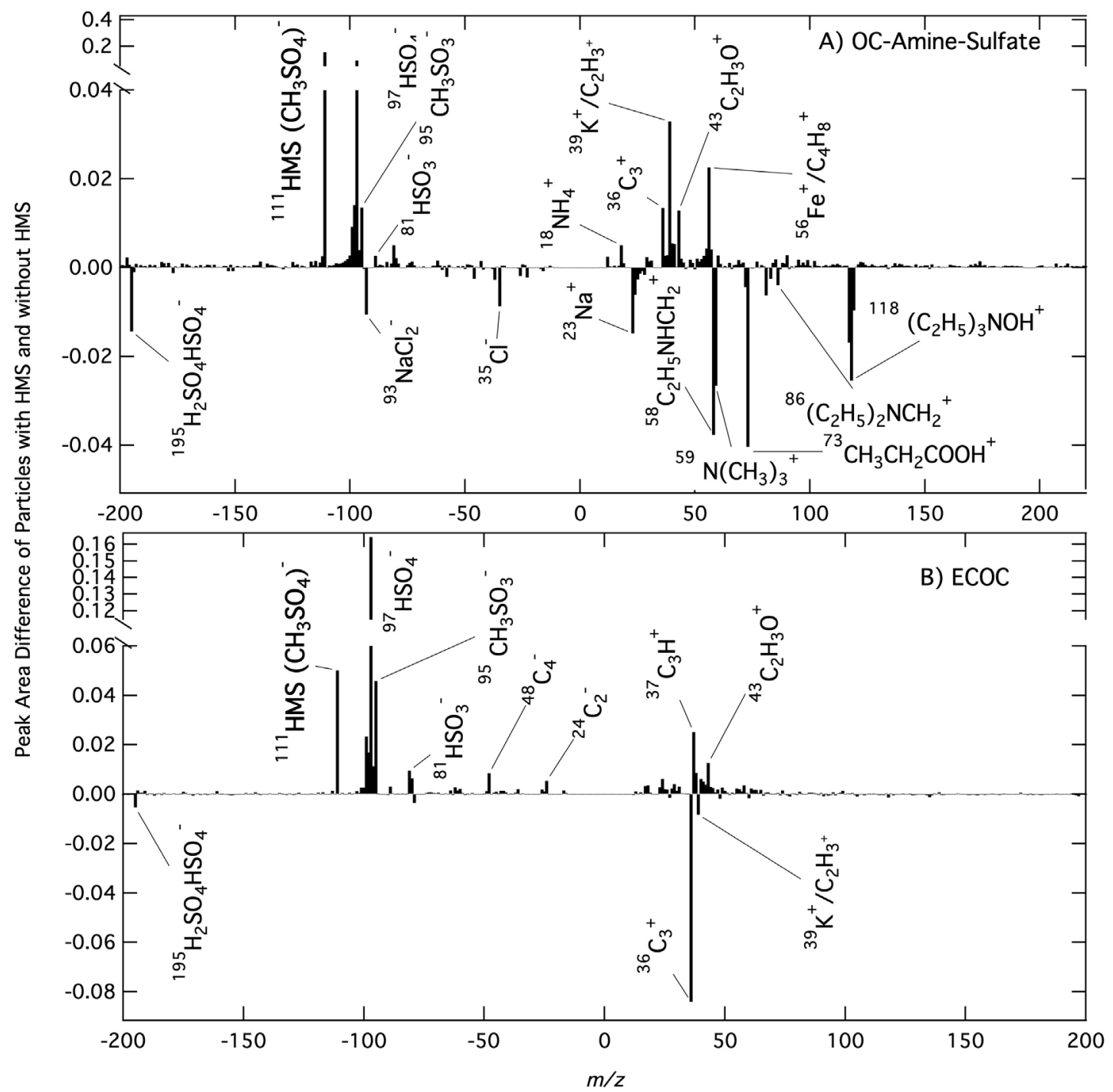

Figure S4. Differences in average A) OC-amine-sulfate and B) ECOC individual particle mass spectra for particles with and without HMS. Positive on the y-axis means ion signals higher in HMS-containing particles, and negative on the y-axis means ion signals higher in particles lacking HMS. 


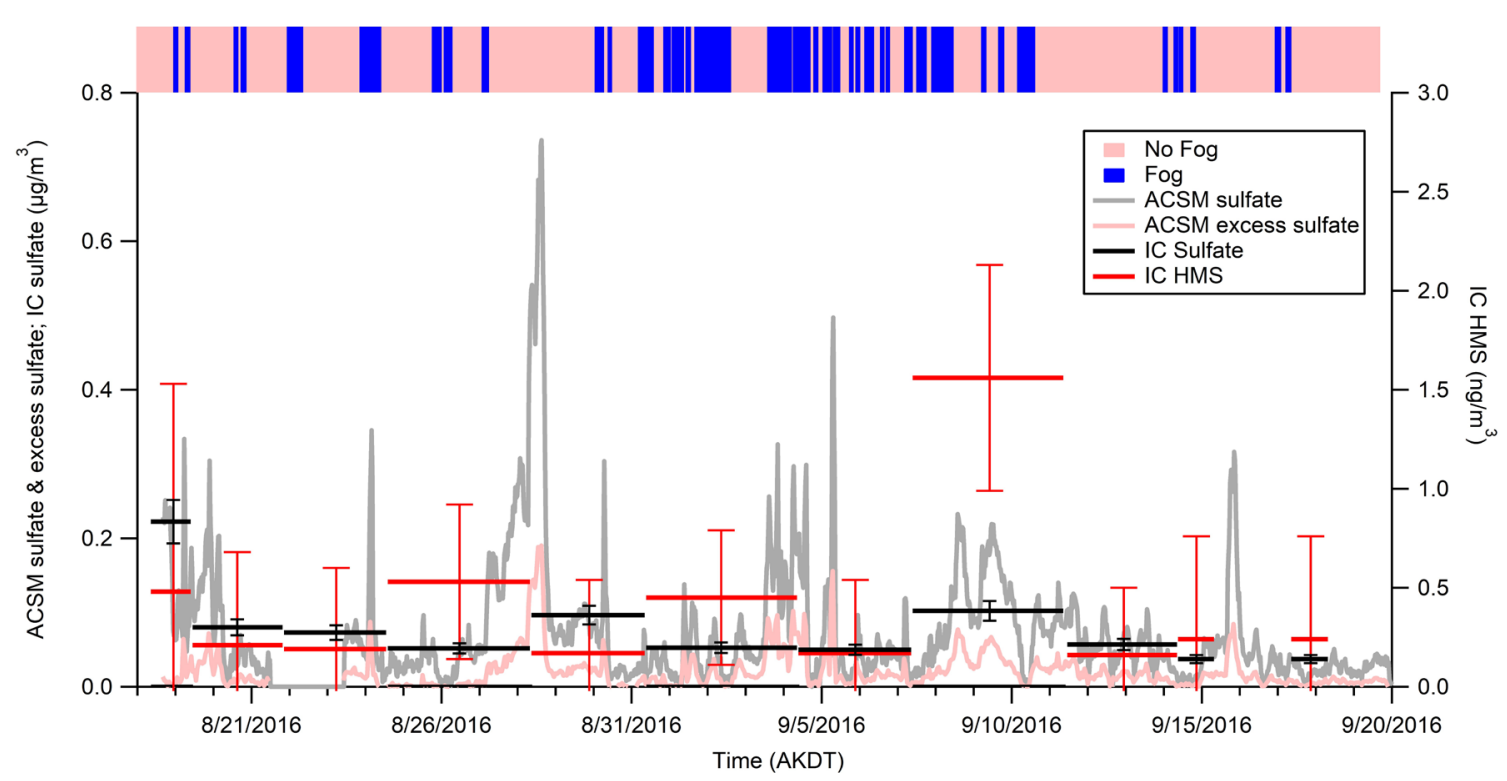

Figure S5. Time series of the mass concentration of sulfate and excess sulfate from ToFACSM measurements at Oliktok Point, AK, as well as HMS and sulfate measured by IC. Oliktok Point fog periods (Figure S2) are also shown. The last filter sample was collected from Sep. 14 9:00 - Sep. 15 7:47 and Sep. 17 8:34 - Sep. 18 7:37, with the break in sampling shown. HMS mass concentrations below the limit of detection are shown as $0.5 \times$ the limit of detection. 


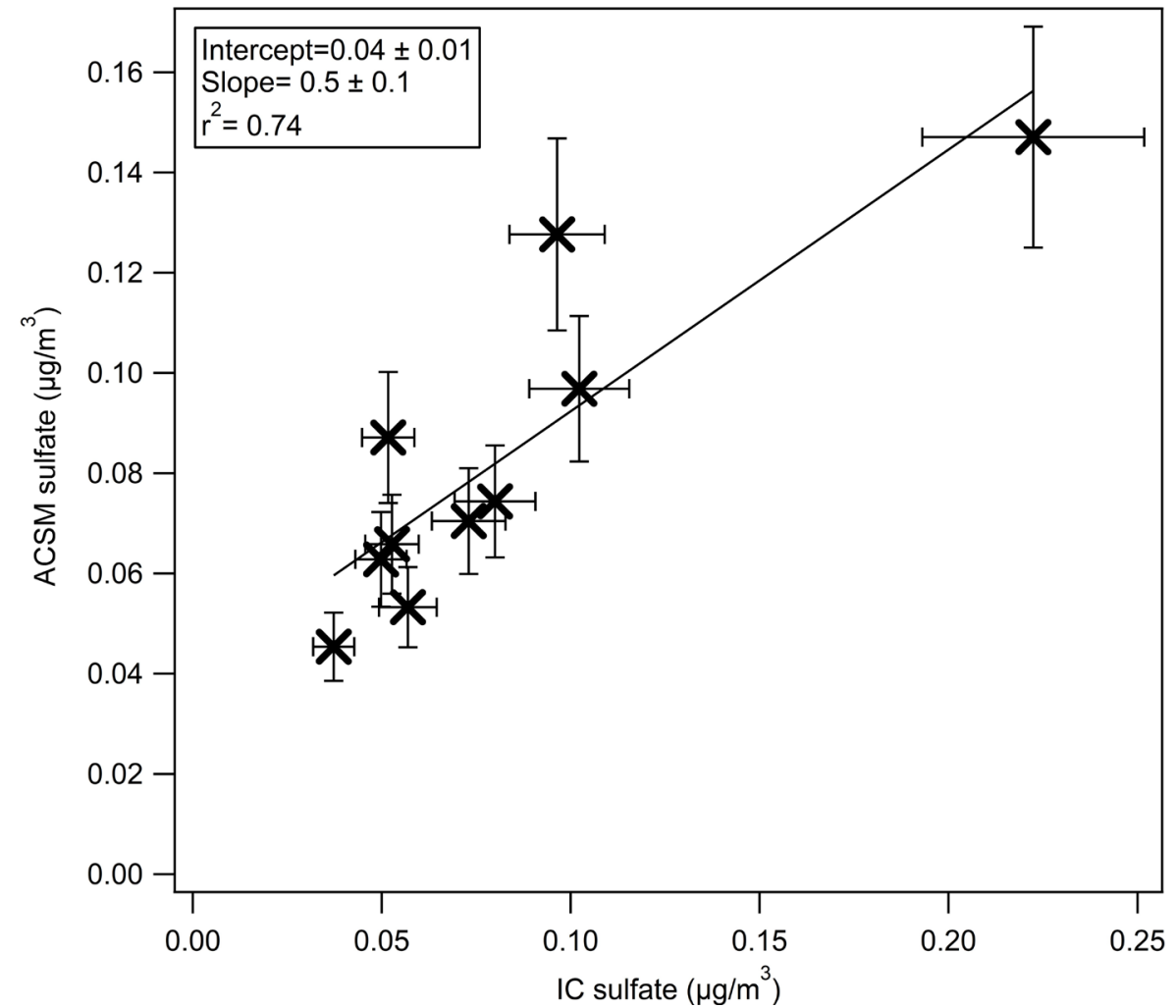

Figure S6. $\mathrm{PM}_{1}$ sulfate measured by ToF-ACSM (averaged by filter sampling periods, with $30 \%$ uncertainty ${ }^{24}$ shown) versus IC, with $20 \%$ uncertainty shown. 
Table S1. Average $\mathrm{SO}_{2}$ and $\mathrm{HCHO}$ concentrations at less than $2000 \mathrm{~m}$ above sea level measurements from the ATom-1 flight campaign. For measurements below the detection limit*, half of the measurement uncertainty values were used in the production rate calculations.

\begin{tabular}{|c|c|c|c|c|c|c|}
\hline Location & Longitude & Latitude & $\begin{array}{c}\text { Altitude } \\
\text { (m) }\end{array}$ & $\begin{array}{l}\text { Date Time } \\
\text { (UTC) }\end{array}$ & $\begin{array}{c}\text { Average } \\
\left.\text { [SO } \mathrm{SO}_{2}\right] \text { (ppb) } \\
\text { (uncertainty) }\end{array}$ & $\begin{array}{c}\text { Average } \\
\text { [HCHO] } \\
\text { (ppb) }\end{array}$ \\
\hline Beaufort Sea 1 & $\begin{array}{c}-136.79 \text { to } \\
-137.77\end{array}$ & $\begin{array}{c}77.90 \text { to } \\
78.46\end{array}$ & $950-2000$ & $\begin{array}{c}8 / 1 / 16 \text { 20:40:00 } \\
\text { to } \\
\text { 8/1/16 20:47:00 }\end{array}$ & $\begin{array}{c}-0.029^{*} \\
(0.022)\end{array}$ & 0.083 \\
\hline Beaufort Sea 2 & $\begin{array}{c}-142.77 \text { to } \\
-142.82\end{array}$ & $\begin{array}{c}78.93 \text { to } \\
78.48\end{array}$ & $200-2000$ & 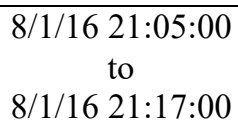 & $\begin{array}{l}0.001^{*} \\
(0.014)\end{array}$ & 0.083 \\
\hline Deadhorse & $\begin{array}{c}-148.22 \text { to } \\
-148.57\end{array}$ & $\begin{array}{c}70.64 \text { to } \\
69.97\end{array}$ & $70-2000$ & $\begin{array}{c}\text { 8/1/16 } 22: 30: 00 \\
\text { to } \\
\text { 8/1/16 } 22: 44: 00\end{array}$ & 0.040 & 0.282 \\
\hline Fairbanks & $\begin{array}{c}-147.98 \text { to } \\
-148.11\end{array}$ & $\begin{array}{c}65.24 \text { to } \\
64.7\end{array}$ & $200-2000$ & 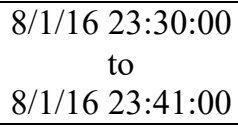 & 0.237 & 0.794 \\
\hline Anchorage & $\begin{array}{c}-150.40 \text { to } \\
-149.98\end{array}$ & $\begin{array}{c}61.43 \text { to } \\
61.17\end{array}$ & $50-2000$ & $\begin{array}{c}8 / 2 / 1600: 31: 00 \\
\text { to } \\
8 / 2 / 1600: 39: 00\end{array}$ & 0.194 & 0.631 \\
\hline
\end{tabular}




\section{References:}

1. Fröhlich, R.; Cubison, M.; Slowik, J.; Bukowiecki, N.; Prévôt, A.; Baltensperger, U.; Schneider, J.; Kimmel, J.; Gonin, M.; Rohner, U., The ToF-ACSM: a portable aerosol chemical speciation monitor with TOFMS detection. Atmospheric Measurement Techniques 2013, 6, (11), 3225-3241.

2. Ng, N. L.; Herndon, S. C.; Trimborn, A.; Canagaratna, M. R.; Croteau, P. L.; Onasch, T. B.; Sueper, D.; Worsnop, D. R.; Zhang, Q.; Sun, Y. L.; Jayne, J. T., An Aerosol Chemical Speciation Monitor (ACSM) for Routine Monitoring of the Composition and Mass Concentrations of Ambient Aerosol. Aerosol Science and Technology 2011, 45, (7), 780-794.

3. Gunsch, M. J.; Liu, J.; Moffett, C. E.; Sheesley, R. J.; Wang, N.; Zhang, Q.; Watson, T. B.; Pratt, K. A., Diesel Soot and Amine-Containing Organic Sulfate Aerosols in an Arctic Oil Field. Environmental Science \& Technology 2019, 54, (1), 92-101.

4. Zhou, S.; Collier, S.; Xu, J.; Mei, F.; Wang, J.; Lee, Y.-N.; Sedlacek, A. J.; Springston, S. R.; Sun, Y.; Zhang, Q., Influences of upwind emission sources and atmospheric processing on aerosol chemistry and properties at a rural location in the northeastern U.S. Journal of Geophysical Research 2016, 121, 6049-6065.

5. Gilardoni, S.; Massoli, P.; Paglione, M.; Giulianelli, L.; Carbone, C.; Rinaldi, M.; Decesari, S.; Sandrini, S.; Costabile, F.; Gobbi, G. P., Direct observation of aqueous secondary organic aerosol from biomass-burning emissions. Proceedings of the National Academy of Sciences 2016, 113, (36), 10013-10018.

6. Ge, X.; Zhang, Q.; Sun, Y.; Ruehl, C. R.; Setyan, A., Effect of aqueous-phase processing on aerosol chemistry and size distributions in Fresno, California, during wintertime. Environmental Chemistry 2012, 9, (3), 221-235.

7. Song, S.; Gao, M.; Xu, W.; Sun, Y.; Worsnop, D. R.; Jayne, J. T.; Zhang, Y.; Zhu, L.; Li, M.; Zhou, Z., Possible heterogeneous chemistry of hydroxymethanesulfonate (HMS) in northern China winter haze. Atmospheric Chemistry and Physics 2019, 19, (2), 1357-1371.

8. Shao, J.; Chen, Q.; Wang, Y.; Lu, X.; He, P.; Sun, Y.; Shah, V.; Martin, R. V.; Philip, S.; Song, S.; Zhao, Y.; Xie, Z.; Zhang, L.; Alexander, B., Heterogeneous sulfate aerosol formation mechanisms during wintertime Chinese haze events: air quality model assessment using observations of sulfate oxygen isotopes in Beijing. Atmos. Chem. Phys. 2019, 19, 6107-6123.

9. Allan, J. D.; Delia, A. E.; Coe, H.; Bower, K. N.; Alfarra, M. R.; Jimenez, J. L.; Middlebrook, A. M.; Drewnick, F.; Onasch, T. B.; Canagaratna, M. R., A generalised method for the extraction of chemically resolved mass spectra from Aerodyne aerosol mass spectrometer data. Journal of Aerosol Science 2004, 35, (7), 909-922.

10. Jayne, J. T.; Leard, D. C.; Zhang, X. F.; Davidovits, P.; Smith, K. A.; Kolb, C. E.; Worsnop, D. R., Development of an aerosol mass spectrometer for size and composition analysis of submicron particles. Aerosol Sci. Technol. 2000, 33, (1-2), 49-70.

11. Farmer, D.; Matsunaga, A.; Docherty, K.; Surratt, J.; Seinfeld, J.; Ziemann, P.; Jimenez, J., Response of an aerosol mass spectrometer to organonitrates and organosulfates and implications for atmospheric chemistry. Proceedings of the National Academy of Sciences 2010, 107, (15), 6670-6675. 
12. Dovrou, E.; Lim, C. Y.; Canagaratna, M. R.; Kroll, J. H.; Worsnop, D. R.; Keutsch, F. N., Measurement techniques for identifying and quantifying hydroxymethanesulfonate (HMS) in an aqueous matrix and particulate matter using aerosol mass spectrometry and ion chromatography. Atmospheric Measurement Techniques 2019, 12, (10), 5303-5315.

13. Whiteaker, J. R.; Prather, K. A., Hydroxymethanesulfonate as a tracer for fog processing of individual aerosol particles. Atmospheric Environment 2003, 37, (8), 1033-1043.

14. Seinfeld, J. H.; Pandis, S. N., Atmospheric Chemistry and Physics: From Air Pollution to Climate Change, 3rd Edition. 3rd ed.; Wiley, New York: New York, NY, 2016; p 1152.

15. Kumai, M., Arctic fog droplet size distribution and its effect on light attenuation. Journal of the Atmospheric Sciences 1973, 30, (4), 635-643.

16. Tang, M.; Cox, R.; Kalberer, M., Compilation and evaluation of gas phase diffusion coefficients of reactive trace gases in the atmosphere: volume 1. Inorganic compounds. Atmospheric Chemistry and Physics 2014, 14, (17), 9233-9247.

17. Xu, J.; Zhang, J. S.; Liu, X.; Gao, Z., Determination of partition and diffusion coefficients of formaldehyde in selected building materials and impact of relative humidity. Journal of the Air \& Waste Management Association 2012, 62, (6), 671679.

18. Sander, R., Compilation of Henry's law constants (version 4.0) for water as solvent. Atmospheric Chemistry \& Physics 2015, 15, (8).

19. Dixon, R. W., Additional mass transport considerations in the formation of hydroxyalkylsulfonates. Atmospheric Environment. Part A. General Topics 1992, 26, (5), 899-905.

20. Rao, X.; Collett, J. L. J., Behavior of S (IV) and formaldehyde in a chemically heterogeneous cloud. Environmental science \& technology 1995, 29, (4), 10231031.

21. Song, X.-H.; Hopke, P. K.; Fergenson, D. P.; Prather, K. A., Classification of single particles analyzed by ATOFMS using an artificial neural network, ART-2A. Analytical chemistry 1999, 71, (4), 860-865.

22. Pratt, K. A.; Prather, K. A., Real-time, single-particle volatility, size, and chemical composition measurements of aged urban aerosols. Environmental science \& technology 2009, 43, (21), 8276-8282.

23. Neubauer, K. R.; Johnston, M. V.; Wexler, A. S., On-line analysis of aqueous aerosols by laser desorption ionization. International journal of mass spectrometry and ion processes 1997, 163, (1-2), 29-37.

24. Budisulistiorini, S. H.; Canagaratna, M. R.; Croteau, P. L.; Baumann, K.; Edgerton, E. S.; Kollman, M. S.; Ng, N. L.; Verma, V.; Shaw, S. L.; Knipping, E. M.; Worsnop, D. R.; Jayne, J. T.; Weber, R. J.; Surratt, J. D., Intercomparison of an Aerosol Chemical Speciation Monitor (ACSM) with ambient fine aerosol measurements in downtown Atlanta, Georgia. Atmos. Meas. Tech. 2014, 7, (7), 1929-1941. 